The University of Maine

DigitalCommons@UMaine

Marine Sciences Faculty Scholarship

School of Marine Sciences

$9-1-2010$

\title{
Seasonal Distribution and Movements of Shortnose Sturgeon and Atlantic Sturgeon in the Penobscot River Estuary, Maine
}

S.J. Fernandes

Gayle Zydlewski

University of Maine - Main, gayle.zydlewski@umit.maine.edu

J.D.Zydlewski

G. S. Wippelhauser

M. T. Kinnison

Follow this and additional works at: https://digitalcommons.library.umaine.edu/sms_facpub

\section{Repository Citation}

Fernandes, S. J.; Zydlewski, Gayle; Zydlewski, J. D.; Wippelhauser, G. S.; and Kinnison, M. T., "Seasonal Distribution and Movements of Shortnose Sturgeon and Atlantic Sturgeon in the Penobscot River Estuary, Maine" (2010). Marine Sciences Faculty Scholarship. 115. https://digitalcommons.library.umaine.edu/sms_facpub/115 


\title{
Seasonal Distribution and Movements of Shortnose Sturgeon and Atlantic Sturgeon in the Penobscot River Estuary, Maine
}

\author{
StePhen J. Fernandes ${ }^{1}$ \\ Environmental and Ecological Sciences, University of Maine, 5741 Libby Hall, \\ Orono, Maine 04469-5741, USA \\ Gayle Barbin ZydLewsKi* \\ School of Marine Sciences, University of Maine, 5741 Libby Hall, Orono, Maine 04469-5741, USA \\ JoSEPH D. ZYDLEWSKI \\ U.S. Geological Survey, Maine Cooperative Fish and Wildlife Research Unit, Nutting Hall, \\ Orono, Maine 04469, USA \\ GaIl S. WipPELHAUSER \\ Maine Department of Marine Resources, 172 State House Station, Augusta, Maine 04333, USA \\ Michael T. KinNisOn \\ School of Biology and Ecology, University of Maine, Murray Hall, Orono, Maine 04469, USA
}

\begin{abstract}
Relatively little is known about the distribution and seasonal movement patterns of shortnose sturgeon Acipenser brevirostrum and Atlantic sturgeon Acipenser oxyrinchus oxyrinchus occupying rivers in the northern part of their range. During 2006 and 2007, 40 shortnose sturgeon (66-113.4 cm fork length [FL]) and 8 Atlantic sturgeon (76.2-166.2 cm FL) were captured in the Penobscot River, Maine, implanted with acoustic transmitters, and monitored using an array of acoustic receivers in the Penobscot River estuary and Penobscot Bay. Shortnose sturgeon were present year round in the estuary and overwintered from fall (midOctober) to spring (mid-April) in the upper estuary. In early spring, all individuals moved downstream to the middle estuary. Over the course of the summer, many individuals moved upstream to approximately $2 \mathrm{~km}$ of the downstream-most dam (46 river kilometers [rkm] from the Penobscot River mouth [rkm 0]) by August. Most aggregated into an overwintering site ( $\mathrm{rkm} 36.5$ ) in mid- to late fall. As many as $50 \%$ of the tagged shortnose sturgeon moved into and out of the Penobscot River system during 2007, and 83\% were subsequently detected by an acoustic array in the Kennebec River, located $150 \mathrm{~km}$ from the Penobscot River estuary. Atlantic sturgeon moved into the estuary from the ocean in the summer and concentrated into a 1.5$\mathrm{km}$ reach. All Atlantic sturgeon moved to the ocean by fall, and two of these were detected in the Kennebec River. Although these behaviors are common for Atlantic sturgeon, regular coastal migrations of shortnose sturgeon have not been documented previously in this region. These results have important implications for future dam removals as well as for rangewide and river-specific shortnose sturgeon management.
\end{abstract}

The shortnose sturgeon Acipenser brevirostrum and Atlantic sturgeon Acipenser oxyrinchus oxyrinchus overlap throughout most of their distributions along the Atlantic coast of North America from Canada to Florida (Moser and Ross 1995). Both species are found in major coastal rivers and estuaries and to varying degrees in marine waters (Gilbert 1989). Shortnose sturgeon display a variation of diadromy wherein the extent of marine migration varies with latitude. In the

\footnotetext{
* Corresponding author: gayle.zydlewski@maine.edu

${ }^{1}$ Present address: 1520 East Sixth Avenue, Post Office Box 200901, Helena, Montana 59620-0901, USA.
}

Received July 8, 2009; accepted May 12, 2010

Published online September 20, 2010 southern part of their range, shortnose sturgeon appear to be estuarine anadromous (NMFS 1998), whereas in northern rivers they appear to be more amphidromous (Bain 1997). Freshwater amphidromy involves migration to and from salt water throughout the life cycle for purposes beyond just breeding (McDowall 1987). Atlantic sturgeon are anadromous throughout their range, and adults commonly spend many years at sea before returning to reproduce in freshwater. Juvenile Atlantic sturgeon spend from 2 to 6 years in riverine and estuarine habitats before migrating to the marine environment (Bain 1997).

Both the shortnose sturgeon and Atlantic sturgeon are species of concern throughout their ranges. The shortnose sturgeon was listed as endangered in 1967 
and remains listed rangewide under the U.S. Endangered Species Act (ESA); the National Marine Fisheries Service (NMFS) now recognizes 19 riverspecific distinct population segments (DPSs) from New Brunswick, Canada, to Florida. In Maine, this includes the Sheepscot-Kennebec-Androscoggin River complex and the Penobscot River. The Gulf of Maine DPS of Atlantic sturgeon has been assessed as having a moderate risk of becoming endangered in the next 20 years (McKown et al. 2005). More recently, Atlantic sturgeon were considered for listing under the ESA, and the status review team identified five DPSs coastwide, with one that encompasses the state of Maine (Atlantic Sturgeon Status Review Team 2007).

Historically, both shortnose sturgeon and Atlantic sturgeon inhabited the Penobscot River as far upstream as river kilometer $(\mathrm{rkm}) 62(\mathrm{rkm} 0=$ Penobscot River mouth), as revealed by archaeological evidence (Knight 1985; Petersen and Sanger 1986), written historical accounts (Holyoke 1870; Godfrey 1882; Westbrook 1897), fishery landing data (e.g., Squiers and Smith 1979; Fernandes 2008), and annual reports of the state of Maine's sea and shore fisheries from 1869 to 1968. Overfishing, pollution, and loss of habitat due to dam construction are the primary causes for the collapse in sturgeon stocks in New England rivers (NMFS 1998). All of these factors are suspected to have affected sturgeon in the Penobscot River (ASMFC 1998). Before this study, however, the contemporary presence of sturgeon in the Penobscot River was uncertain.

The most recent confirmed documentation of sturgeon in the Penobscot River system was in 1978, when a single shortnose sturgeon was captured in Penobscot Bay (Northport, Maine, downstream of rkm 0 ) in the leads of an experimental floating fish trap operated by the Maine Department of Marine Resources (Squiers and Smith 1979). This suggested the possibility that a shortnose sturgeon population persisted in the Penobscot River (NMFS 1998). In 1994 and 1995, a directed survey was conducted by the Maine Department of Marine Resources to determine the presence of shortnose sturgeon in the upper estuary near the head of tide. No sturgeon were captured during 409 h of gill-net effort (T. S. Squiers, Maine Department of Marine Resources, unpublished data). In 2005, an angler reported capture of a sturgeon (approximately $1.5 \mathrm{~m}$ long) in the Penobscot River at Brewer near rkm 37 (Holyoke 2005). This capture, along with upcoming status assessments and pending dam removal, encouraged NMFS to reconsider the status of both the shortnose sturgeon and Atlantic sturgeon in the Penobscot River system.

The objective of this study was to document the presence, seasonal distribution, and movement patterns of shortnose sturgeon and Atlantic sturgeon in the Penobscot River estuary. Acoustic telemetry was used to identify movements that may be related to spawning, foraging, and overwintering. Such information is critical in assessing the potential influence of planned restoration actions in the Penobscot River. As part of the Penobscot River Restoration Project, the two lowest dams (Great Works and Veazie dams) will be removed. The project is anticipated to reestablish access of both sturgeon species to their entire historical range within the next 5 years.

\section{Field Methods}

\section{Methods}

Capture and processing.-Shortnose sturgeon and Atlantic sturgeon were captured with multifilament nylon gill nets ( $2.44 \mathrm{~m}$ high $\times 90$ or $45 \mathrm{~m}$ long) fished from May to November in 2006 and 2007. Gill-net set locations ranged between rkm 7 and rkm 46, and set times ranged from 0.2 to $23.8 \mathrm{~h}$. Putative adult (45-120 $\mathrm{cm}$ fork length [FL]) and subadult (45-55 cm FL) shortnose sturgeon and subadult $(60-135 \mathrm{~cm}$ FL) Atlantic sturgeon were targeted using nets with a stretch mesh size of $15.2 \mathrm{~cm}$. Putative adult shortnose sturgeon (45-120 cm FL) and adult Atlantic sturgeon $(>135 \mathrm{~cm}$ FL) were targeted using nets with a stretch mesh size of $30.5 \mathrm{~cm}$.

Upon capture, both shortnose sturgeon and Atlantic sturgeon were assessed for condition and placed in a temporary floating holding pen $(1.5 \times 0.9 \times 1.25 \mathrm{~m})$ prior to further data recording. Initially, MS-222 (tricaine methanesulfonate) was used to anesthetize fish for handling. Subsequently, fish were immobilized by placing them upside down in a mesh sling within a water-filled sampling trough to eliminate risks due to anesthesia (Moser et al. 2000). Fish were visually identified to species, which was later verified using the ratio of mouth width to interorbital distance (Dadswell et al. 1984). Measurements of total length, FL, mass, interorbital width, and mouth width were recorded, and an endoscopic examination was performed using the methods of Kynard and Kieffer (2002) to assess fish maturity status and sex. A small piece of dorsal fin tissue was taken for associated population genetic analyses (see King et al. 2010; Wirgin et al. 2010).

All fish were scanned for a passive integrated transponder (PIT) tag using an AVID PowerTracker VIII PIT reader. If a fish was untagged, a $134.2-\mathrm{kHz}$ PIT tag was implanted just below the dorsal fin and above the lateral row of scutes. Each fish was also tagged with an external numeric Carlin dangler tag just below or anterior to the dorsal fin. Individuals were allowed to recover in the temporary floating holding 
pen before being released directly into the river at the site of capture.

Transmitters.-We implanted both coded and continuous (noncoded) acoustic transmitters into 40 shortnose sturgeon (21 in 2006; 19 in 2007) and 8 Atlantic sturgeon (4 in 2006; 4 in 2007). Coded transmitters allowed identification of individual fish and provided information on fish temperature and depth (water pressure). Continuous transmitters assisted with active tracking. The transmitters (all produced by VEMCO, Halifax, Nova Scotia) included three coded models and one continuous model. Coded models included V9P2L (equipped with pressure sensors; $9 \mathrm{~mm}$ in diameter $\times 47 \mathrm{~mm}$ long; $3.5 \mathrm{~g}$ in water), V13TP-1L, and $\mathrm{V} 13 \mathrm{TP}-1 \mathrm{H}$ (equipped with temperature and pressure sensors; $13 \times 45 \mathrm{~mm}$; $6 \mathrm{~g}$ in water); all coded transmitters broadcasted at $69 \mathrm{kHz}$. The continuous model, V16-1H (16 $\times 54 \mathrm{~mm}$; $9 \mathrm{~g}$ in water), operated on a single frequency between 51 and $81 \mathrm{kHz}$ with ping periods of $1-2 \mathrm{~s}$.

Tag implantation.-Surgeries to implant transmitters were only attempted when fish appeared to be in excellent condition and when water temperature was between $7^{\circ} \mathrm{C}$ and $27^{\circ} \mathrm{C}$. Internal tagging was avoided if a fish was considered to be in prespawning condition during early spring-summer. One potential prespawning Atlantic sturgeon was tagged externally by following methods similar to those of Buckley and Kynard (1985). All other tag implantation procedures were conducted according to the methods of Moser et al. (2000). Briefly, each fish was positioned during surgery by placing it upside down in a mesh sling within a water-filled sampling trough, with its head submerged for gill perfusion. A scalpel was used to make a 3-4-cm ventral incision just off the midline of the fish, and the tag was inserted anteriorly. The incision was closed with two sets of sutures: (1) a set of 3-0 chromic cat gut (dissolvable) sutures spanning the outer dermal layer of skin and the peritoneum and (2) a set of $2-0$ or 3-0 monofilament or silk thread (nondissolvable) sutures through the outer dermal layer only. Fish were held in river water for at least $1 \mathrm{~h}$ to confirm their recovery prior to release.

Acoustic receiver array.-An array of 82 (in 2006) or 83 (in 2007) stationary acoustic receivers (VEMCO VR2) was deployed at up to 39 monitoring sites in the Penobscot River estuary and Penobscot Bay (Figure 1). The array was cooperatively maintained during April through November each year by the University of Maine, NMFS, and the U.S. Geological Survey (USGS) Maine Cooperative Fish and Wildlife Research Unit. For the purpose of this study, the Penobscot River system consists of the Penobscot River estuary and Penobscot Bay. The estuary is defined as the area from the head of tide at Veazie Dam (rkm 47) to the southernmost point on Verona Island (rkm 0); Penobscot Bay is defined as the area extending roughly $90 \mathrm{~km}$ from the southern point of Verona Island to the Gulf of Maine.

Supplemental winter detections were made by intermittently deploying portable receivers into the Penobscot River from shore in December 2006 and February and March 2007. In 2007, the Maine Department of Marine Resources deployed and maintained a similar array in the Kennebec River complex, approximately $150 \mathrm{~km}$ southwest of Penobscot Bay.

Stationary receivers were equipped with omnidirectional hydrophones and monitored continuously at 69 $\mathrm{kHz}$. At each monitoring site, single or multiple receivers were deployed to receive tag information from the entire width of the river, estuary, or bay (or significant tributary stream). Receivers were moored on the bottom at estuarine sites and suspended at approximately $10 \mathrm{~m}$ below the surface in the bay. Data were downloaded from receivers every 2 months. Differences in receiver positioning were minor between years, amounting to reduction in the number of bay sites and an increase in the number of estuarine sites to better resolve fish movements in 2007. Several receivers were lost each year, and hydrodynamic conditions at some sites probably prevented tags from always being detected. Only positive detections were used to characterize fish movements (i.e., extrapolation and interpolation were not used in the absence of actual detections).

\section{Quantitative Methods}

Telemetry data processing.-Conflicting data were removed by inspecting and filtering for incorrect sensor data. Detections with values outside the possible physical limits for temperature or depth of a site were removed; simultaneous detections of a single transmitter at two geographically separated locations were also removed. To avoid the possibility of false detections, any transmitter (fish) that was not detected at least five times in a 24-h period was not used in calculations. Finally, if a transmitter completely stopped movement, the sensor data were examined to assess whether the transmitter was probably still associated with a live fish ("active" tag). Tags were considered "inactive" in a fish if vertical and lateral movements ceased (excluding simple tidal oscillations) for a period greater than 8 weeks. Detections of inactive tags were filtered from the database to avoid including expelled tags or dead fish as viable records. The total number of active tags in the estuary was used to report the proportions of fish exhibiting certain behaviors; the number of active tags 


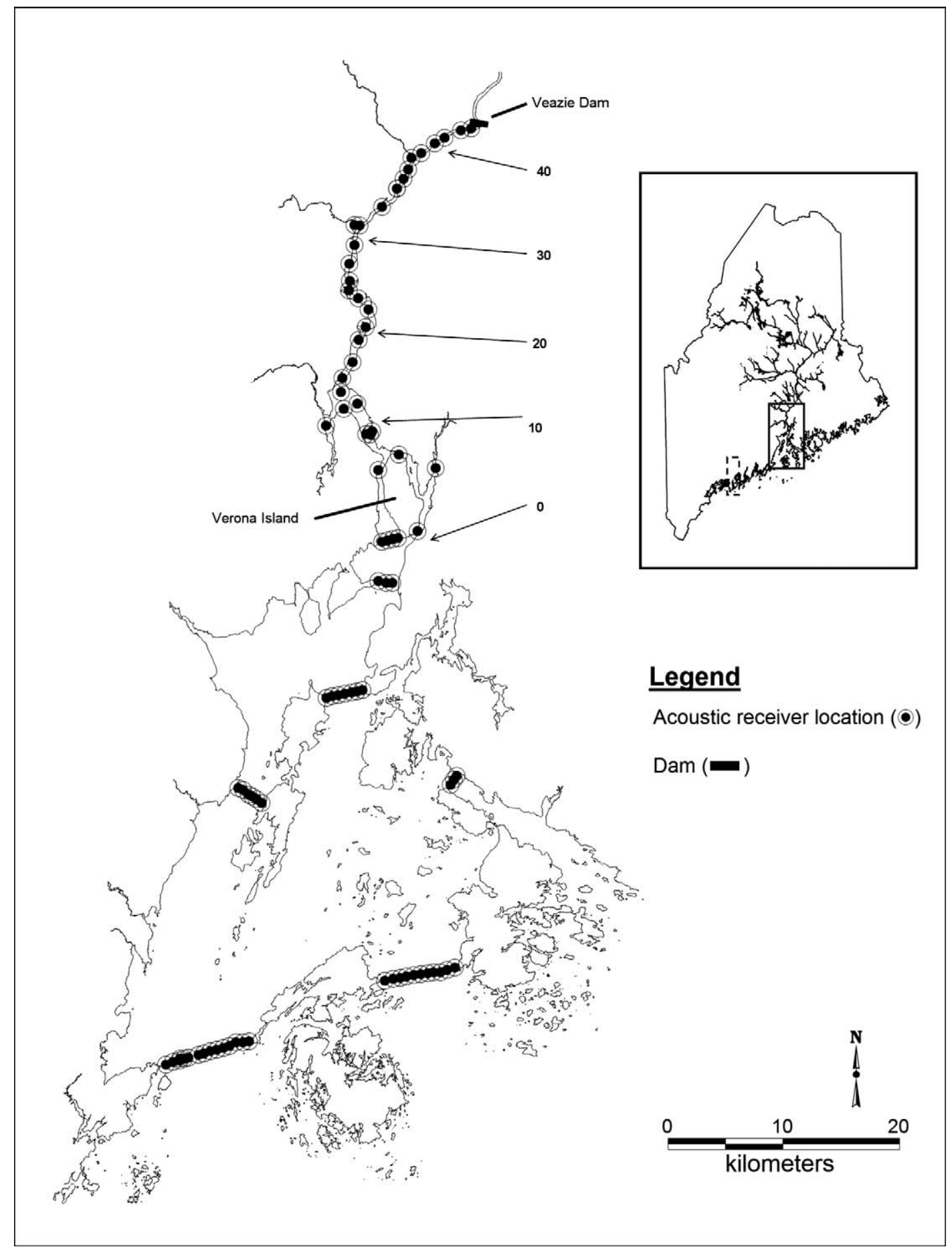

Figure 1.- Map of the Penobscot River and Penobscot Bay, Maine. Veazie Dam delineates the upper boundary of habitat accessible to shortnose sturgeon and Atlantic sturgeon. Verona Island delineates the boundary between the Penobscot River estuary and Penobscot Bay. Dots represent acoustic receiver locations in 2007. River kilometers (0-40) are indicated with arrows. Inset shows the location of the Penobscot River system (box with solid border) within Maine, and the dashed box indicates the mouth of the Kennebec River, which is approximately $150 \mathrm{~km}$ (coastal distance) from the Penobscot River estuary. 


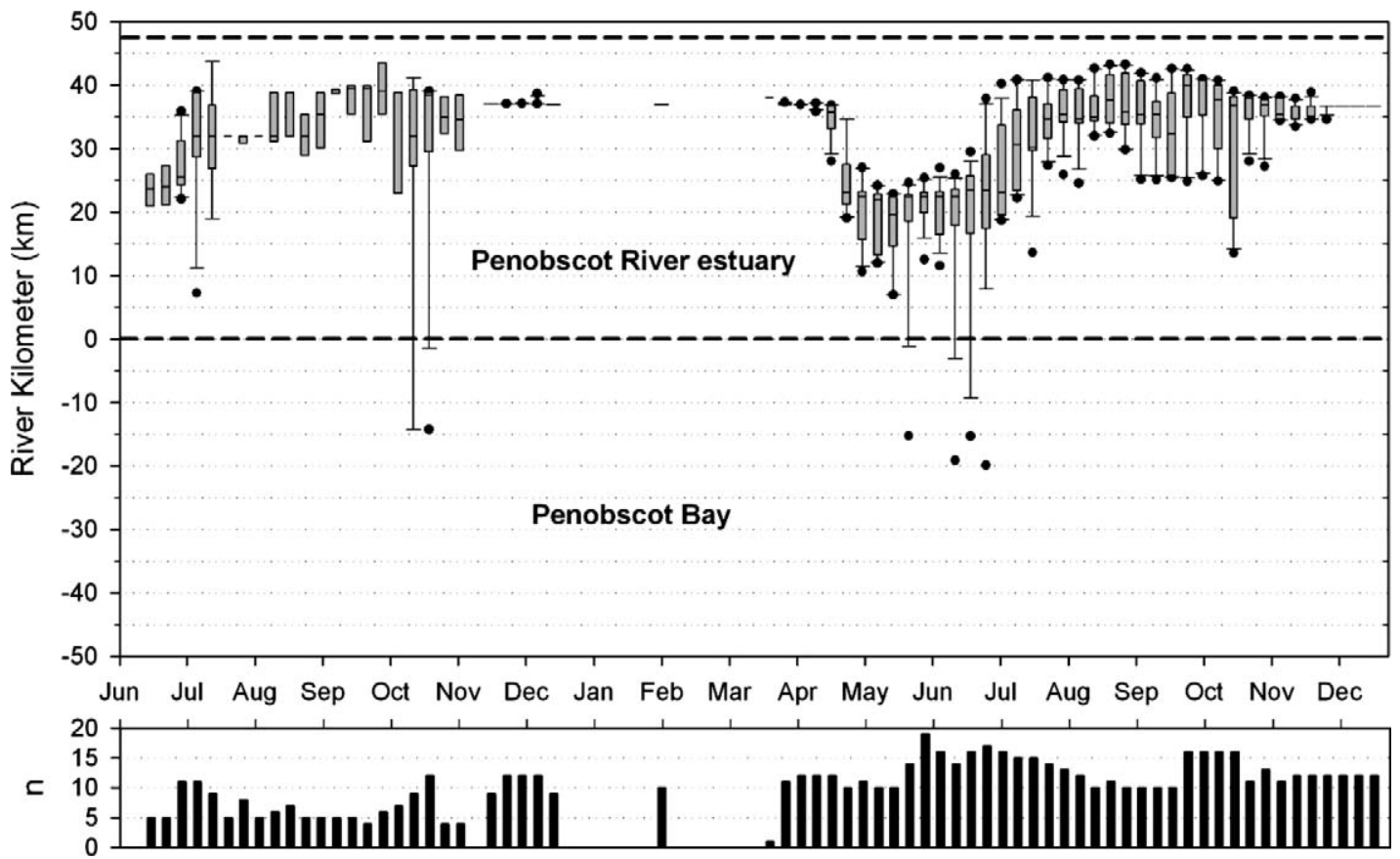

FIGURE 2.-Box plot of weekly river kilometer locations of shortnose sturgeon in the Penobscot River, Maine (box ends $=25$ th and 75th percentiles of ultrasonic tag detections; line within box $=$ median; error bars [whiskers] $=10$ th and 90th percentiles; dots = outliers). Upper dashed line represents Veazie Dam, and lower dashed line represents southern Verona Island. The chart below the box plot shows the number of fish $(n)$ represented for each week.

did not include individuals that had left the estuary prior to the period of interest.

Mean daily rkm was determined for each fish by calculating the mean rkm of all detections for that fish in a 24-h period. Mean weekly rkm values were calculated from the daily means for each fish and were used to construct box plots of the weekly river distributions of acoustic-tagged fish. Emigration was defined as downstream movement out of the Penobscot River estuary and a subsequent lack of detection for at least 1 week. Immigration was defined as the subsequent detection of an emigrant on one or more Penobscot River receivers. Because gillnetting effort was not evenly distributed throughout the river, such data were used to verify the presence and abundance of untagged fish in areas of fish with transmitters.

Environmental data.-Mean daily river temperature (MDT) for the Penobscot River at the USGS gauging station at Eddington, Maine (rkm 47), and mean daily river discharge (MDD) at the USGS gauging station at West Enfield, Maine (rkm 101), were obtained from the USGS water data website (www.waterdata.usgs. gov). Water temperature data were available for August 22, 2006, to November 29, 2007; discharge data were available for June 1, 2006, to January 10 , 2007, and for
April 16-November 29, 2007. Data for January 11April 15, 2007, were not available due to ice.

\section{Results}

Shortnose Sturgeon Seasonal Distribution and Movement Patterns

Data from net capture and acoustic telemetry indicate that shortnose sturgeon were present in the Penobscot River from June 14, 2006, to December 2007 (Figure 2). Between June and October 2006, 63 adults and subadults were captured (and 1 was recaptured) in multiple gill-net sets between rkm 13.9 and rkm 42.2. From late May to early November 2007, there were 99 captures (87 individuals and 12 recaptures) between $\mathrm{rkm} 21.0$ and $\mathrm{rkm}$ 41.8. Fish size ranged from 66 to $113.4 \mathrm{~cm}$ FL. The mean $( \pm \mathrm{SE})$ water depth of acoustic-tagged shortnose sturgeon over the entire study was $6.4 \pm 0.05 \mathrm{~m}$. The following seasonal movement patterns were documented in the Penobscot River system: overwintering, spring downstream movement, late spring-early summer immigration and emigration, summer upstream movement, and fall emigration and movement. In addition, shortnose sturgeon were documented as moving back and forth between two geographically separate river systems. 


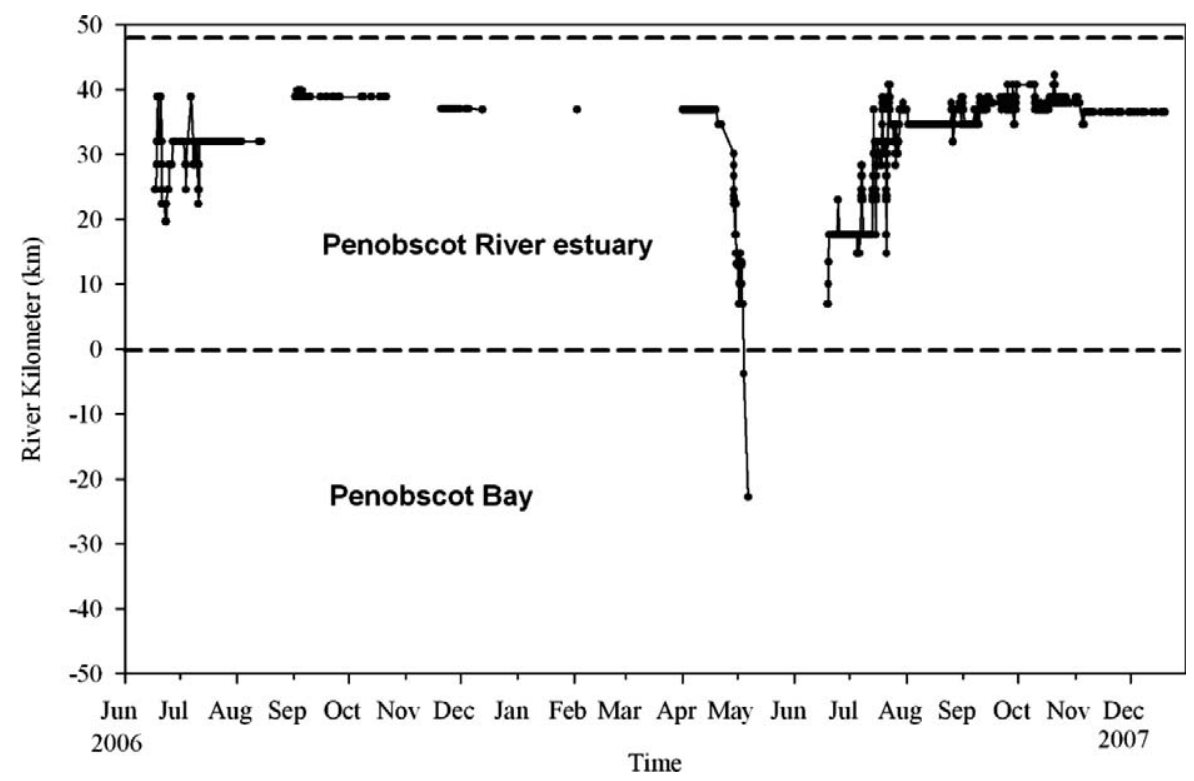

FIGURE 3.- Movements of an individual shortnose sturgeon tagged in the Penobscot River, Maine, and detected between June 2006 and December 2007 (dots = individual detections). Upper dashed line represents Veazie Dam, and lower dashed line represents southern Verona Island.

Overwintering.-Shortnose sturgeon overwintered in the Penobscot River in both 2006-2007 and 20072008. Eighty percent (12 of 15 fish) of active acoustictagged shortnose sturgeon were concentrated in a single location near rkm 36.5 in mid-October 2006, and $50 \%$ (11 of 23 fish) were concentrated there in midOctober 2007 (Figures 2, 3). In 2006, this group included three individuals that were previously identified as females carrying late-stage eggs. Using a shore-deployed receiver, 9-12 individuals were detected between December 12 and 13, 2006; 10 individuals were detected on February 2, 2007; and 11-12 fish were detected from March 23 to 27 and from March 30 to April 2, 2007. The full 2007 receiver array was deployed on April 11, 2007, which allowed for the detection of these fish leaving the overwintering site approximately 1 week later (Figure 2). The size of the area where the fish were aggregated was approximately $1,400 \mathrm{~m}^{2}$. Other untagged individuals used this river location, as inferred from the gill-net capture of 18 shortnose sturgeon in this 2-km section (rkm 36.538.4) during a 3-week period in early October 2006 and 3 individuals in early November 2007.

Spring downstream movement.-All acoustic-tagged shortnose sturgeon left the overwintering site and moved downstream by April 19, 2007 (Figures 2, 3), including females carrying late-stage eggs. From the end of April to mid-June, most acoustic-tagged fish made use of the lower estuary (rkm 10.0-24.5), with a small number $(n=3)$ of individuals moving out into Penobscot Bay or out of the system entirely (note whiskers and outliers for May-July 2007 in Figure 2). Capture data indicate that other shortnose sturgeon in addition to the telemetered individuals used the lower to middle part of the estuary during this period. Nearly $50 \%(49.2 \%)$ of the shortnose sturgeon captures in 2006 occurred during a 2-week period in late June and $60 \%$ of captures in 2007 occurred in late May to early June, with all but one capture in the location between rkm 21 and rkm 23 (gill-net sets were unevenly distributed between rkm 7 and $\mathrm{rkm}$ 41.2).

Late-spring and early-summer immigration and emigration.-Six acoustic-tagged shortnose sturgeon were detected as moving out of the Penobscot River estuary and into Penobscot Bay in the spring and early summer of 2006 and 2007. In 2006, one fish left the estuary in the first week of July; in 2007, five fish left the estuary after detections on May 6, 12, and 16 and June 2 and 28.

Immigration of acoustic-tagged shortnose sturgeon was documented in spring and early summer 2007. Two of the shortnose sturgeon that moved out of the system in fall 2006 returned on May 17 and 25, 2007. In 2007, one individual left the estuary on May 6 and re-entered the system just 6 weeks later (Figure 3). 
Summer upstream movement.-Starting in late June, all acoustic-tagged shortnose sturgeon (10 in 2006; 16 in 2007) began shifting their distribution upstream from the lower and middle portions of the estuary. By mid-July of both years, all shortnose sturgeon had moved upstream and were located between rkm 24.5 and rkm 42.2; by August, most were between rkm 32 and rkm 45 (Figures 2, 3). During July and August 2006, 13 untagged shortnose sturgeon were captured between rkm 21.0 and $\mathrm{rkm} 42.2$, confirming the presence of additional untagged individuals in the region. In 2007, there were 6 captures from rkm 21.0 to rkm 34.8 during July and 3 captures at rkm 34.9 in August. Twenty-seven percent of the captures in 2007 (27 individuals) occurred during a 2-week period of late September to early October within a 1-km section of the upper estuary (rkm 40.7-41.8).

Fall emigration and movement.-Some individuals emigrated from the Penobscot River system in fall 2006 and 2007. Two individuals left the system in 2006 (October 6 and 7). These are the same two individuals that returned to the system in spring 2007 (on May 7 and 25). In 2007, seven individuals left the system between September 18 and November 4 .

A period of increased movement was noted among nonemigrating fish during this period. In August, the mean daily rkm range was less than $4 \mathrm{rkm}$ on all but 3 $\mathrm{d}$ ( $2 \mathrm{~d}$ in 2006; $1 \mathrm{~d}$ in 2007), whereas it exceeded $4 \mathrm{rkm}$ on $9 \mathrm{~d}$ in September ( $2 \mathrm{~d}$ in 2006; $7 \mathrm{~d}$ in 2007) and on $17 \mathrm{~d}$ in October (8 $\mathrm{d}$ in 2006; $9 \mathrm{~d}$ in 2007). This variation in movement resulted in a small shift in the mean distribution of fish downstream but was not as extensive as the downstream migration of individuals in the spring (Figure 2).

Coastal movements of shortnose sturgeon.-During 2007, 12 shortnose sturgeon with acoustic transmitters (42\% of active tags) were detected leaving the Penobscot River system; 10 of these were subsequently detected on the acoustic receiver array in the Kennebec River in 2007. This is a minimum coastal distance of approximately $150 \mathrm{~km}$ (west) from the mouth of the Penobscot River (rkm 0) to the first receiver encountered in the Kennebec River (near the Sasanoa River). Three of the four individuals that emigrated from the Penobscot River system in the spring were detected as moving into the Kennebec River system in spring and summer. One individual was last detected as leaving Penobscot Bay on May 6 and was detected in the Kennebec River on June 2-a movement of over 150 $\mathrm{km}$ in $26 \mathrm{~d}$. This individual returned to the Penobscot River estuary on June 18 after being at large for another 16 d. The two other individuals displayed similar patterns, emigrating on May 12 (detected in the Kennebec River on July 9 after 57 d at large) and
June 2 (detected in the Kennebec River on August 24 after $82 \mathrm{~d}$ at large). The remaining seven coastal migrants detected by the Kennebec River array left the Penobscot River estuary in the fall (between September 18 and November 4); these fish were at large for a shorter period (6-19 d). Five of these seven fish were last detected in a known shortnose sturgeon overwintering area within the lower Kennebec River during February 2008.

Further evidence of interriver exchange between the Kennebec and Penobscot rivers was documented in 2007, when two individuals that were originally captured and PIT-tagged in 1998 and 1999 as part of another study in the Kennebec River (Squiers 2003) were captured in the Penobscot River on June 11 and July 12, 2007.

\section{Atlantic Sturgeon Seasonal Distribution and Movement Patterns}

Capture and acoustic telemetry data indicated that Atlantic sturgeon were present in the Penobscot River from as early as late May to October (July 4-October 24, 2006, and May 25-October 23, 2007; Figure 4). Over the 2 years, 35 Atlantic sturgeon were captured from rkm 20.4 to $\mathrm{rkm} 36.5$, with $88.6 \%$ of captures obtained between rkm 21.0 and rkm 24.5 (Figure 1). Fish size ranged from 71.2 to $166.2 \mathrm{~cm}$ FL. The mean ( $\pm \mathrm{SE}$ ) water depth of acoustic-tagged Atlantic sturgeon over the entire study was $10.3 \pm 0.1 \mathrm{~m}$. Both capture and telemetry data revealed that Atlantic sturgeon occupied a very narrow section of the estuary, with little upstream and downstream movements outside of immigration and emigration (Figures 4, 5). Three movement patterns were observed: (1) concentration into a small area of the estuary during the late spring and summer, (2) summer immigration, and (3) fall emigration. In addition, coastal movements between the Penobscot and Kennebec rivers were documented.

Late-spring and summer concentration.-In 2006, seven subadult Atlantic sturgeon were captured from July to October. Five of these fish were captured in July and August between rkm 26.6 and rkm 29.4, and two fish were captured in October at rkm 36.5. In 2007, 28 Atlantic sturgeon (26 subadults and 2 potential adults) were captured from late May to the end of July between rkm 21.0 and rkm 26.4.

During their time in the Penobscot River system, all seven Atlantic sturgeon that received acoustic tags in 2007 concentrated in a $1.5-\mathrm{km}$ reach of the estuary between rkm 23 and rkm 24.5 (Figures 4, 5); none of these fish were encountered outside of this reach unless they were immigrating into the system or emigrating. In 2007 , the mean daily rkm of Atlantic sturgeon was 


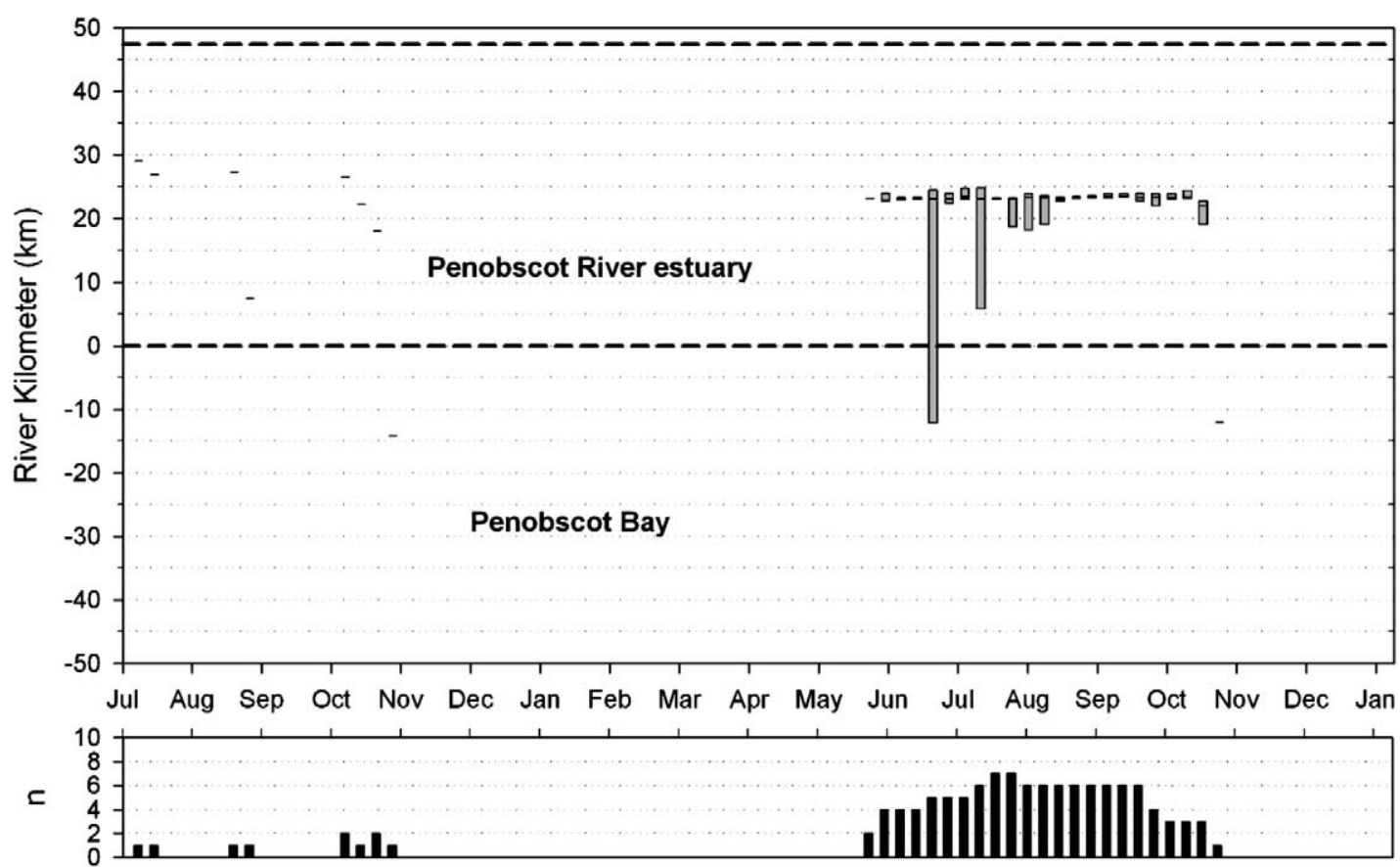

FIGURE 4.-Box plot of weekly river kilometer locations of Atlantic sturgeon in the Penobscot River, Maine (box ends $=25$ th and 75th percentiles of acoustic tag detections; line within box = median; error bars and outliers are not shown due to the close aggregation of fish). Upper dashed line represents Veazie Dam, and lower dashed line represents southern Verona Island. The chart below the box plot shows the number of fish $(n)$ represented for each week.

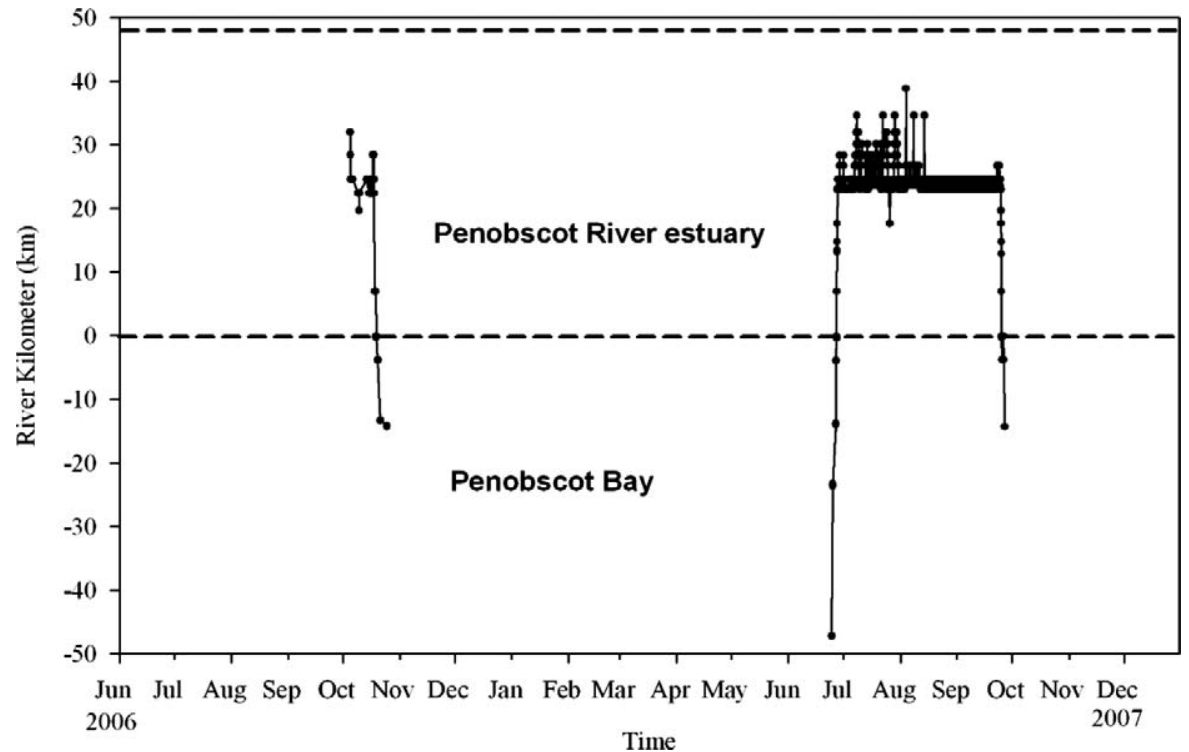

Figure 5.- Movements of an individual Atlantic sturgeon tagged in the Penobscot River, Maine, and detected between October 2006 and October 2007 (dots = individual detections). Upper dashed line represents Veazie Dam, and lower dashed line represents southern Verona Island. 


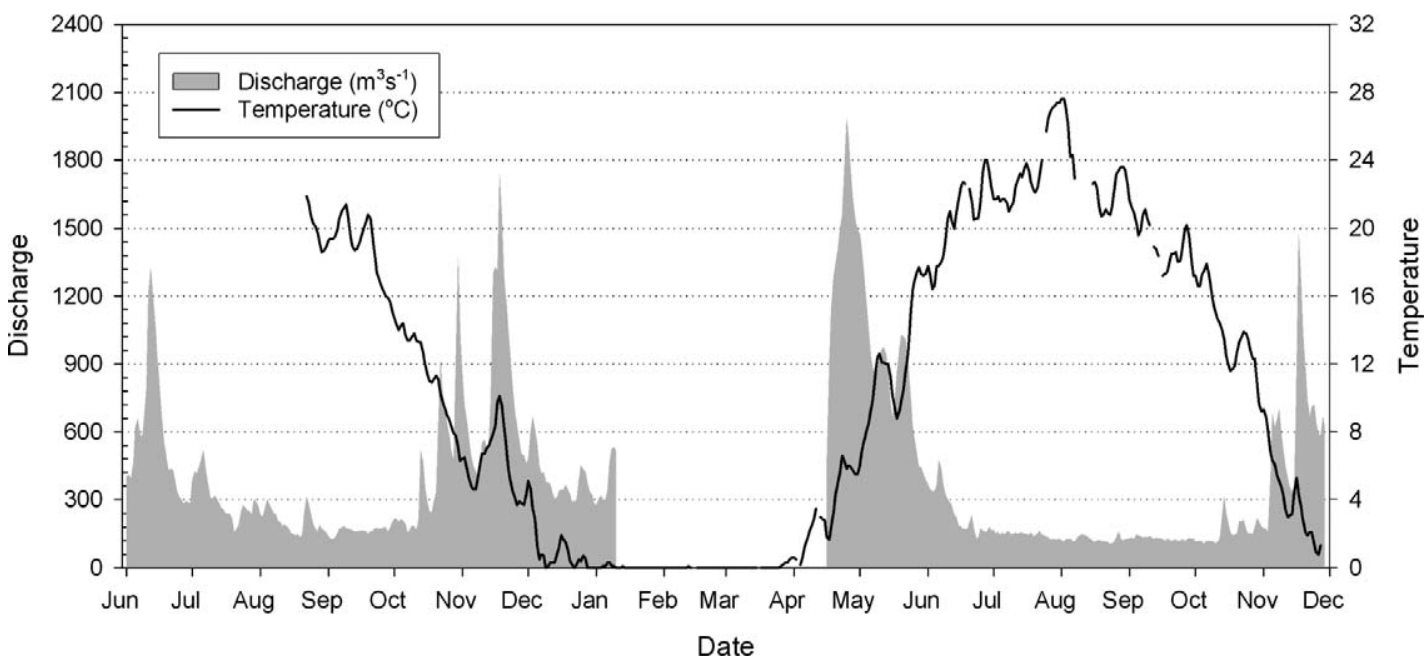

FIguRE 6.- Mean daily discharge $\left(\mathrm{m}^{3} / \mathrm{s}\right)$ and freshwater temperature $\left({ }^{\circ} \mathrm{C}\right)$ of the Penobscot River, as measured at the U.S. Geological Survey gauging station at West Enfield, Maine, during June 2006 through November 2007.

within this reach for $75.4 \%$ of the days (on average) during which Atlantic sturgeon were detected. This percentage was lower in $2006(40 \%)$.

Summer immigration and fall emigration.-Atlantic sturgeon immigration occurred from spring to mid-July based on the movements of two individuals that were tagged in 2006 and returned to the estuary in 2007. These 2007 immigration events occurred on June 24 and July 14 (Figure 4: the two box plots extending downstream past rkm 10; one individual shown in Figure 5).

Most of the acoustic-tagged Atlantic sturgeon in the estuary emigrated from the system either in midSeptember or mid-October: two of three fish in 2006 and five of seven fish in 2007 (Figures 4, 5). There were several fish that left the estuary and entered Penobscot Bay soon after being tagged earlier in the year. One individual was tagged on August 19, 2006, and left the estuary within $36 \mathrm{~h}$. One large, potentially mature individual was externally tagged at $\mathrm{rkm} 21$ on July 21,2007 ; this fish only remained in the estuary for a few days before emigrating.

Coastal movements.-Three Atlantic sturgeon that were detected as leaving the Penobscot River estuary and Penobscot Bay (1 fish in 2006; 2 fish in 2007) were subsequently detected by the receiver array in the Kennebec River. One fish left the Penobscot River system in mid-October 2006 and was detected in the Kennebec River for 2 weeks in October 2007. The second fish was the large, potentially mature individual that was externally tagged in the Penobscot River system during July 2007. This fish was detected in the Kennebec River $7 \mathrm{~d}$ after its last detection in Penobscot
Bay. It was detected intermittently in the Kennebec River through the middle of October. The third fish left the Penobscot River system in October 2007 and was soon detected in the Kennebec River (October 31November 4, 2007).

\section{Environmental Factors}

Temperature, discharge, and tides of the Penobscot River strongly influence the dynamics of environmental conditions in the estuary and affect the entire study area. In both 2006 and 2007, the MDT of the Penobscot River peaked by mid-August, dropped to nearly $0^{\circ} \mathrm{C}$ in December, and remained there until the following spring (Figure 6). The spring peak in MDD of the river occurred in April (2007); in both years, MDD dropped to below $300 \mathrm{~m}^{3} / \mathrm{s}$ during the summer, with several subsequent spikes in late October and November.

\section{Discussion}

Distribution and movement patterns of shortnose sturgeon and Atlantic sturgeon in the Penobscot River system in 2006 and 2007 revealed some unexpected patterns, especially for the putatively amphidromous shortnose sturgeon. Prior to this study, movements of shortnose sturgeon were believed to be restricted to the natal river systems. We present the first evidence of a northern shortnose sturgeon population exhibiting extensive movements through the fully saline coastal environment to another nearby river known to support spawning. Despite such movements, the lower Penobscot River nonetheless appears to be critical habitat for this endangered species given that shortnose sturgeon 
were present in the Penobscot River estuary year-round and aggregated in the upper estuary during the winter. Our data also suggest that shortnose sturgeon moved downstream to the middle estuary in spring, gradually moved back upriver during the summer, and entered the overwintering area in the fall. Emigration of shortnose sturgeon from the Penobscot River system occurred in the spring and fall and immigration occurred in the spring. Atlantic sturgeon within the Penobscot River system were found to aggregate into a discrete reach of the middle estuary, showing limited upstream or downstream movement during the spring and summer. Atlantic sturgeon exhibited estuarine immigration during the summer and emigration from the system in the fall and were also detected as moving between river systems.

\section{Shortnose Sturgeon}

Many of the coastal movements of shortnose sturgeon tagged in the Penobscot River resulted in detections in the adjacent Kennebec River. Additional captures of two PIT-tagged individuals from a separate study in the Kennebec River provide further evidence that these interriver movements are not isolated events. These are significant findings because occurrences of shortnose sturgeon in the marine environment are so rare (Bain et al. 2007). Indeed, it is even arguable whether such cases reflect natural behaviors for this species. For example, Smith et al. (2002) found evidence for the coastal wandering of shortnose sturgeon stocked in the Savannah River, GeorgiaSouth Carolina, which they attributed to the lack of imprinting by stocked fish. In contrast, intersystem movements appear to be exceedingly common for Penobscot River fish, with up to $42 \%$ of the active tagged population undertaking such movements. Marine movements also appear to occur in a repeatable seasonal pattern and in a highly directed fashion. Nearly all marine emigrants from the Penobscot River (83\%) were accounted for by detections in the Kennebec River. In combination, these observations suggest the presence of a true migratory life history strategy that involves interriver movements via marine habitats.

Several general possibilities exist regarding the distinctiveness of the Penobscot River shortnose sturgeon for ESA-related management. One possibility is that a breeding population of shortnose sturgeon exists in the Penobscot River system but has always had a high degree of demographic exchange with the population of the Kennebec-Androscoggin River system (i.e., divergent ancestral population). The second possibility is that an incipient population has recently become established in the Penobscot River system through colonization from the Kennebec and Androscoggin rivers (i.e., recent colonization). A third possibility is that fish from the Kennebec-Androscoggin River population use the Penobscot River system as a distant outpost for feeding and overwintering (i.e., single population). Genetic samples collected in this study were analyzed by Wirgin et al. (2010) and King et al. (2010); those authors found that haplotype and allelic frequencies of shortnose sturgeon in the Kennebec and Penobscot rivers were nearly identical, potentially supporting all three of the above scenarios. More research is needed to better distinguish among these alternatives, but the combined molecular and movement data in hand would suggest that the Penobscot River shortnose sturgeon should be grouped with those from the Kennebec and Androscoggin rivers in a common evolutionary management unit that recognizes this potentially unique migratory strategy.

The noted aggregation of a large proportion of tagged shortnose sturgeon into a small area of the upper estuary from late fall to early spring of the next year is typical. Shortnose sturgeon are known to concentrate in one or a few overwintering locations in their presumed natal river during late fall as water temperatures decrease (Dadswell 1979). The early to mid-October movement of shortnose sturgeon into the Penobscot River overwintering site occurred when MDD was $518 \mathrm{~m}^{3} / \mathrm{s}$ and MDT was $13.3^{\circ} \mathrm{C}$ in 2006 and when MDD was $208 \mathrm{~m}^{3} / \mathrm{s}$ and MDT was $13.3^{\circ} \mathrm{C}$ in 2007. Fish appear to be moving into the overwintering area at similar temperatures but at different levels of discharge. The role of other environmental factors (changing photoperiod, for example) remains to be assessed. The discovery of an overwintering site in the Penobscot River is the first step towards identifying and protecting important habitats used by shortnose sturgeon in this system.

In the lower Connecticut River (Connecticut), Saint John River (New Brunswick, Canada), and Altamaha River (Georgia), prespawning shortnose sturgeon usually migrate to their spawning grounds in the fall, spend the winter nearby, and spawn during the following spring (Dadswell 1979; Buckley and Kynard 1985). Three ripening individuals overwintered in the Penobscot River; however, none of these individuals (or any other acoustic-tagged fish) moved upstream in the spring. Downstream movement from the overwintering site $(n=12)$ occurred simultaneously with increasing river discharge by April 19, 2007, when the MDD was approximately $1,300 \mathrm{~m}^{3} / \mathrm{s}$ (and rapidly approaching $2,000 \mathrm{~m}^{3} / \mathrm{s}$ ) and when the MDT was $3.3^{\circ} \mathrm{C}$ and rising (Figure 6). Spawning of shortnose sturgeon in the Connecticut River has been correlated with the timing of discharge spikes in relation to the windows of 
day length and temperature (Boyd E. Kynard, USGS Conte Anadromous Fish Laboratory, unpublished data). Assuming that spawning occurs in the Penobscot River, it is possible that the high discharge in 2007 affected the timing of optimal spawning conditions and disrupted the occurrence of prespawning and spawning migrations, as has been reported in other river systems (Dadswell 1979; Buckley and Kynard 1985; Kynard 1997). However, spawning has not been documented in the Penobscot River, and all surveys to date have targeted large individuals.

The movement of shortnose sturgeon out of the overwintering site occurred in mid-April when the water temperature was $2.4^{\circ} \mathrm{C}$. Shortnose sturgeon as far south as the Delaware River form spawning aggregations in March-April and then rapidly move downstream with nonspawning fish in April-May (O'Herron et al. 1993). Nonspawning shortnose sturgeon in the Merrimack River, Massachusetts, left the overwintering site from May to June at water temperatures of approximately $13-14^{\circ} \mathrm{C}$ and after other individuals had spawned (Kieffer and Kynard 1993). These populations are farther south, but the individuals left overwintering locations at the same time as or later than shortnose sturgeon in the Penobscot River. This may suggest some form of population divergence in seasonal phenology, but additional data are needed.

Shortnose sturgeon are associated with the upriver limit of the salt wedge in many river systems (Hall et al. 1991; Kieffer and Kynard 1993; O'Herron et al. 1993). Similarly, the distribution of shortnose sturgeon in the Penobscot River estuary may be related to the intrusion of salt water because the distribution seems to correspond roughly with Haefner's (1967) description of its seasonally changing location. Haefner (1967) stated that the "geographical location of the inner end of the Penobscot estuary varies seasonally in relation to river discharge." It was found that at peak discharge in April, freshwater extends to rkm 17. As river discharge decreases and flood tides penetrate farther upstream into the river, the freshwater section becomes compressed, with the downstream limit of salinity intrusion located at rkm 31 in June and at rkm 42 in August. The freshwater limit gradually advances downstream to $\mathrm{rkm}$ 34.5 as river discharge increases in the fall. The conditions of the Penobscot River may have changed somewhat since Haefner's (1967) depiction of the Penobscot River estuary's hydrography because of the breaching of the Bangor Dam (at rkm 42) in 1977 and much lower pollution levels. However, these data are useful for characterizing the dynamics of saltwater intrusion in the absence of more recent data.

Both capture and telemetry data in the Penobscot River revealed a shortnose sturgeon aggregation area near rkm 21.0 in late spring and early summer; this area was probably used for foraging. The downstream movements of shortnose sturgeon into this middle part of the estuary, into Penobscot Bay, and even out of the system in spring occurred during periods of high $(1,700$ $\mathrm{m}^{3} / \mathrm{s}$ ) and subsequently decreasing river discharge (down to $200 \mathrm{~m}^{3} / \mathrm{s}$ ). Such movements also occurred to a lesser degree during periods of decreasing temperature and increasing discharge in the fall. Shortnose sturgeon moved upstream and concentrated in the upper part of the Penobscot River estuary during mid- to late July, when discharge was at its lowest and when MDT increased from $23^{\circ} \mathrm{C}$ to its annual peak of $27.6^{\circ} \mathrm{C}$. When temperatures rose above $28.0^{\circ} \mathrm{C}$, shortnose sturgeon in the Savannah River moved upstream to a location with an average salinity of $0.1 \%$, whereas during periods of lower water temperatures they used further downstream river sections with salinities as high as $17.6 \%$ (Collins et al. 2002). Dadswell (1979) also described a general upriver movement of the entire shortnose sturgeon population during summer in the Saint John River estuary. The reason for the similar movement pattern in the Penobscot River is unknown. However, it may be in response to a physiological preference for a combination of salinity and water temperature conditions or to an upstream shift in the available prey base corresponding with the intrusion of the saline wedge.

\section{Atlantic Sturgeon}

Unlike shortnose sturgeon, Atlantic sturgeon were found to use the Penobscot River estuary for only part of the year; capture data suggested that the majority of Atlantic sturgeon inhabiting the Penobscot River are encountered as early as late May until the end of October between rkm 21.0 and rkm 24.5. The earliest confirmed presence of Atlantic sturgeon was in late May 2007, when river discharge was dropping after the peak MDD of about $560 \mathrm{~m}^{3} / \mathrm{s}$ and when MDT was about $17^{\circ} \mathrm{C}$. The one potential adult that was given an external acoustic tag in the Penobscot River estuary did not migrate upstream to apparent spawning habitat. Within $3 \mathrm{~d}$ of tagging, this individual left the system and was later detected in the Kennebec River system. This fish could have spawned prior to capture, could have aborted spawning due to capture and handling, or might have been a nonspawning or large immature individual.

The movement of Atlantic sturgeon between the Penobscot and Kennebec rivers is consistent with coastal and marine movements observed for both mature and immature Atlantic sturgeon (Atlantic Sturgeon Status Review Team 2007). Smith et al. (1984) and Smith (1985) reported subadult Atlantic 
sturgeon migrating from North Carolina to Long Island, New York $(645 \mathrm{~km})$; from South Carolina to Virginia (466 km) and North Carolina $(595 \mathrm{~km})$; and from Quebec to Nova Scotia $(559 \mathrm{~km})$.

While in the Penobscot River estuary, Atlantic sturgeon inhabited a very small $1.5-\mathrm{km}$ reach (at $\mathrm{rkm}$ 23.0-24.5) from late May to the end of October, moving out of the estuary when river discharge was on the rise and when temperature was falling. The aggregation area is significantly deeper $(>15 \mathrm{~m}$ deep at mean low water) than any other part of the estuary upstream of rkm 8 and experiences a bottom salinity as high as 10\%o at low summer discharge (Haefner 1967). This habitat in the Penobscot River estuary is similar to the deep, saline estuarine areas with reduced flow that are used by Atlantic sturgeon in the Hudson River (Bain et al. 2000) and Merrimack River (Kieffer and Kynard 1993). Hatin et al. (2002) found that most tagged Atlantic sturgeon detections were at sites deeper than $10 \mathrm{~m}$ in the St. Lawrence River (93\%) and estuary (90\%), Canada. In the lower Cape Fear River, North Carolina, Moser and Ross (1995) also found that sonictagged Atlantic sturgeon did not move much in the summer and held at depths in excess of $10 \mathrm{~m}$ throughout the year. The depth information from the acoustic transmitters (mean depth $\pm \mathrm{SE}=10.3 \pm 0.1$ $\mathrm{m}$ ) in our study substantiates the use of deep areas in the Penobscot River estuary by Atlantic sturgeon.

The fall movement of Atlantic sturgeon out of the Penobscot River estuary and the return of individuals in the summer are consistent with the paradigm that subadult Atlantic sturgeon primarily inhabit estuarine regions during summer and move into higher-salinity waters during late fall and winter when temperatures decrease (Collins and Smith 1997). During this time, they can be found in deeper, saline portions of rivers or in coastal waters (Smith 1985). Lazzari et al. (1986) found that subadult Atlantic sturgeon in the upper tidal Delaware River overwintered in deep waters of the lower estuary and moved upstream during spring in response to increasing water temperatures. Subadult Atlantic sturgeon in the Hudson River moved downstream into brackish water to overwinter when water temperatures dropped below $20^{\circ} \mathrm{C}$ (Bain 1997). This is significantly higher than the Penobscot River temperature at which emigration took place $\left(12^{\circ} \mathrm{C}\right.$ during midto late October) in 2006 and 2007. This difference in migration timing could be a result of latitudinal variation in behavior.

The spatial distribution of tagged shortnose sturgeon and Atlantic sturgeon in the Penobscot River estuary overlapped in the spring and summer from late May to mid-July (Figures 2, 4). Other than this period and the fall period when shortnose sturgeon are emigrating, there is very little overlap in the distributions of these two species. The distributions of adult shortnose sturgeon and subadult Atlantic sturgeon within river systems of the Northeast are generally correlated with salinity. Shortnose sturgeon occur in freshwater and weakly saline reaches, whereas Atlantic sturgeon occupy higher-salinity reaches (Kieffer and Kynard 1993). Atlantic sturgeon also occupied deeper habitats on average (mean depth $\pm \mathrm{SE}=10.3 \pm 0.1 \mathrm{~m}$ ) than shortnose sturgeon $(6.4 \pm 0.05 \mathrm{~m})$ during their time in the Penobscot River estuary. However, shortnose sturgeon have also been found to choose areas with greater flow rates than Atlantic sturgeon, and the separate distributions may actually be partly based on flow preferences (as proposed by COSEWIC 2005).

\section{Closing Comments}

This study has provided new information regarding the status and behavior of threatened and endangered sturgeon species in a poorly studied part of their range. Documenting the high proportion of movements of shortnose sturgeon between geographically separate river systems was not an original objective of this study; however, this is a particularly significant observation in terms of the biology and management of the species. Much of the shortnose sturgeon's seasonal distribution and movements within the river is similar to that of sturgeon in other northern river systems as well as in systems throughout the species' range. However, extensive and directed coastal movements serve to distinguish shortnose sturgeon in this system from those in other parts of the species' range. The identification of important or critical habitats for both the shortnose sturgeon and Atlantic sturgeon and the extent of their use is a substantial step towards the protection and conservation of these species. Moreover, such information may provide useful baseline data describing the period before the removal of dams and the restoration of currently inaccessible historical habitat. More research is needed to evaluate whether either species spawns successfully in the Penobscot River, to characterize the features of such habitat, and to better understand the proximate basis and extent of sturgeon movements among coastal river systems in Maine.

\section{Acknowledgments}

This research was funded by a grant from NMFS (National Oceanic and Atmospheric Administration [NOAA] Fisheries). All methods were conducted under NOAA ESA Section 10 Permit Number 1595 for take of protected species for scientific purposes. Additional support was provided by the USGS Maine Cooperative Fish and Wildlife Research Unit, the University of 
Maine, the Maine Department of Marine Resources, and The Nature Conservancy. This project would not have been possible without the assistance of the NOAA Fisheries Maine Field Office and the many graduate and undergraduate students, faculty, staff, and volunteers who contributed time and effort. We thank Boyd Kynard and Micah Kieffer at the USGS S.O. Conte Anadromous Fish Laboratory. The manuscript benefited from the reviews of James Hawkes and James McCleave. Mention of trade names does not imply endorsement by the U.S. Government. This paper is Contribution Number 3134 of the Maine Agricultural and Forest Experiment Station.

\section{References}

ASMFC (Atlantic States Marine Fisheries Commission). 1998. Atlantic sturgeon stock assessment. ASMFC, Peer Review Report, Washington, D.C.

Atlantic Sturgeon Status Review Team. 2007. Status review of Atlantic sturgeon (Acipenser oxyrinchus oxyrinchus). Report to the National Marine Fisheries Service, Northeast Regional Office, Gloucester, Massachusetts.

Bain, M., N. Haley, D. Peterson, J. R. Waldman, and K. Arend. 2000. Harvest and habitats of Atlantic sturgeon Acipenser oxyrinchus Mitchill, 1815 in the Hudson River estuary: lessons for sturgeon conservation. Boletín Instituto Espánol de Oceanografía 16:43-53.

Bain, M. B. 1997. Atlantic and shortnose sturgeons of the Hudson River: common and divergent life history attributes. Environmental Biology of Fishes 48:347-358.

Bain, M. B., N. Haley, D. L. Peterson, K. K. Arend, K. E. Mills, and P. J. Sullivan. 2007. Recovery of a U.S. endangered fish. PLoS ONE 2:e168.

Buckley, J., and B. Kynard. 1985. Yearly movements of shortnose sturgeons in the Connecticut River. Transactions of the American Fisheries Society 114:813-820.

Collins, M. R., W. C. Post, D. C. Russ, and T. I. J. Smith. 2002. Habitat use and movements of juvenile shortnose sturgeon in the Savannah River, Georgia-South Carolina. Transactions of the American Fisheries Society 131:975979.

Collins, M. R., and T. I. J. Smith. 1997. Distributions of shortnose and Atlantic sturgeons in South Carolina. North American Journal of Fisheries Management 17:995-1000.

COSEWIC (Committee on the Status of Endangered Wildlife in Canada). 2005. COSEWIC assessment and update status report on the shortnose sturgeon Acipenser brevirostrum in Canada. COSEWIC, Ottawa.

Dadswell, M. J. 1979. Biology and population characteristics of the shortnose sturgeon, Acipenser brevirostrum LeSueur 1818 (Osteichthyes: Acipenseridae), in the Saint John River estuary, New Brunswick, Canada. Canadian Journal of Zoology 57:2186-2210.

Dadswell, M. J., B. B. Taubert, T. S. Squiers, D. Marchette, and J. Buckley. 1984. Synopsis of biological data on shortnose sturgeon, Acipenser brevirostrum Lesueur 1818. NOAA Technical Report NMFS 14.

Fernandes, S. J. 2008. Population demography, distribution, and movement patterns of Atlantic and shortnose sturgeons in the Penobscot River estuary, Maine. Master's thesis. University of Maine, Orono.

Gilbert, C. R. 1989. Species profiles: life histories and environmental requirements of coastal fishes and invertebrates (Mid-Atlantic Bight): Atlantic and shortnose sturgeons. U.S. Fish and Wildlife Service Biological Report 82(11.122).

Godfrey, J. E. 1882. History of Penobscot County, Maine, with illustrations and biographical sketches. Williams Chase, Cleveland, Ohio.

Haefner, P. A. Jr. 1967. Hydrography of the Penobscot River (Maine) estuary. Journal of the Fisheries Research Board of Canada 24:1553-1571.

Hall, W. J., T. I. J. Smith, and S. D. Lamprecht. 1991. Movements and habitats of shortnose sturgeon Acipenser brevirostrum in the Savannah River. Copeia 1991:695702.

Hatin, D., R. Fortin, and F. Caron. 2002. Movements and aggregation areas of adult Atlantic sturgeon (Acipenser oxyrinchus) in the St. Lawrence River estuary, Quebec. Canadian Journal of Applied Ichthyology 18:586-594.

Holyoke, J. 1870. The centennial celebration of the settlement of Bangor, September 30, 1869. Benjamin A. Burr, Bangor, Maine.

Holyoke, J. 2005. Brewer angler hooks five-foot sturgeon during lunch break. Bangor Daily News (July 9).

Kieffer, M. C., and B. Kynard. 1993. Annual movements of shortnose and Atlantic sturgeons in the Merrimack River, Massachusetts. Transactions of the American Fisheries Society 122:1088-1103.

King, T. L., A. P. Henderson, B. E. Kynard, M. C. Kiefer, D. L. Peterson, and D. S. Pavek. 2010. A nuclear DNA perspective on delineating fundamental units of management and distinct population segments in the endangered shortnose sturgeon (Acipenser brevirostrum). Draft report to the U.S. National Park Service National Capital Region and U.S. Geological Survey, Eastern Region, Kearneyville, West Virginia.

Knight, J. A. 1985. Differential preservation of calcined bone at the Hirundo site, Alton, Maine, Master's thesis, University of Maine, Orono.

Kynard, B. 1997. Life history, latitudinal patterns, and status of the shortnose sturgeon, Acipenser brevirostrum. Environmental Biology of Fishes 48:319-334.

Kynard, B., and M. Kieffer. 2002. Use of a borescope to determine the sex and egg maturity stage of sturgeons and the effect of borescope use on reproductive structures. Journal of Applied Ichthyology 18:505-508.

Lazzari, M. A., J. C. O'Herron, and R. W. Hastings. 1986. Occurrence of juvenile Atlantic sturgeon, Acipenser oxyrinchus, in the upper tidal Delaware River. Estuaries 9:356-361.

McDowall, R. M. 1987. The occurrence and distribution of diadromy among fishes. Pages 1-13 in J. Dadswell, R. J. Klauda, C. M. Moffitt, R. L. Saunders, R. A. Rulifson, and J. E. Cooper, editors. Common strategies of anadromous and catadromous fishes. American Fisheries Society, Symposium 1, Bethesda, Maryland.

McKown, K., T. Meyer, T. Smith, B. Spear, and D. St. Pierre. 2005. Review of the Atlantic States Marine Fisheries Commission fishery management plan for Atlantic 
sturgeon (Acipenser oxyrinchus) for 2003. Atlantic States Marine Fisheries Commission, Washington, D.C.

Moser, M. A., and S. W. Ross. 1995. Habitat use and movements of shortnose and Atlantic sturgeons in the lower Cape Fear River, North Carolina. Transactions of the American Fisheries Society 124:225-234.

Moser, M. L., M. Bain, M. R. Collins, N. Haley, B. Kynard, J. C. O'Herron II, G. Rogers, and T. S Squiers. 2000. A Protocol for use of shortnose and Atlantic sturgeons. NOAA Technical Memorandum NMFS-OPR-18. Available: nmfs.gov/prot_res/prot_res.html. (July 2009).

NMFS (National Marine Fisheries Service). 1998. Recovery plan for the shortnose sturgeon (Acipenser brevirostrum). Prepared by the Shortnose Sturgeon Recovery Team for the National Marine Fisheries Service, Silver Spring, Maryland.

O'Herron, J. C., K. W. Able, and R. W. Hastings. 1993. Movements of shortnose sturgeon (Acipenser brevirostrum) in the Delaware River. Estuaries 16:235-240.

Petersen, J. B., and D. Sanger. 1986. Archaeological phase II testing at the Eddington Bend site (74-8). Penobscot County, Maine. Report submitted to Bangor HydroElectric Company by the University of Maine, Orono.

Smith, T. I. J. 1985. The fishery, biology and management of Atlantic sturgeon, Acipenser oxyrinchus, in North America. Environmental Biology of Fishes 14:61-62.
Smith, T. I. J., D. E. Marchette, and G. F. Ulrich. 1984. The Atlantic sturgeon fishery in South Carolina. North American Journal of Fisheries Management 4:164-176.

Smith, T. I. J., J. W. McCord, M. R. Collins, and W. C. Post. 2002. Occurrence of stocked shortnose sturgeon Acipenser brevirostrum in non-target rivers. Journal of Applied Ichthyology 18:470-474.

Squiers, T. S. 2003. Kennebec River shortnose sturgeon population study 1998-2001. Maine Department of Marine Resources, Completion Report, Reference Document 01/20, Augusta.

Squiers, T. S., and M. Smith. 1979. Distribution and abundance of shortnose and Atlantic sturgeon in the Kennebec River estuary. Maine Department of Marine Resources, Completion Report, Project AFC-19, Augusta.

Westbrook, T. 1897. Letter from Thos Westbrook to Gov. Shute Sept. 23, 1722. Pages 153-156 in J. P. Baxter, editor. Documentary history of the state of Maine containing the Baxter manuscripts. Heritage Books, Portland, Maine.

Wirgin, I., C. Grunwald, J. Stabile, and J. R. Waldman. 2010. Delineation of discrete population segments of shortnose sturgeon Acipenser brevirostrum based on mitochondrial DNA control region sequence analysis. Conservation Genetics 11:689-708. 